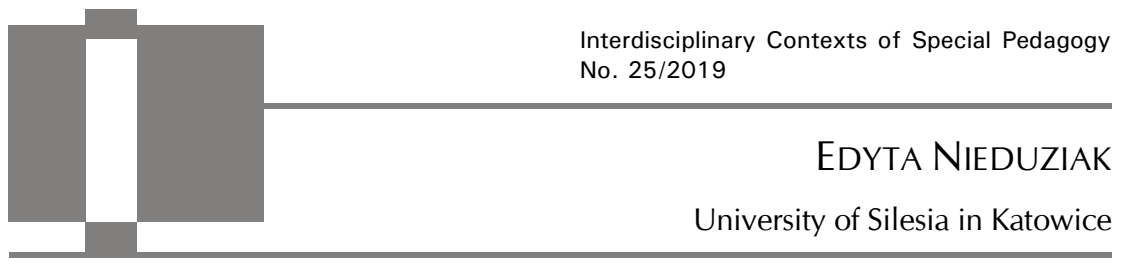

\title{
Towards a radical life. The social and aesthetic themes in Helen Keller's activity in defence of humanity ${ }^{1}$
}

\begin{abstract}
Edyta Nieduziak, Towards a radical life. The social and aesthetic themes in Helen Keller's activity in defence of humanity. Interdisciplinary Contexts of Special Pedagogy, no. 25, Poznań 2019. Pp. 229-254. Adam Mickiewicz University Press. ISSN 2300-391X. DOI: https://doi.org/10.14746/ikps.2019.25.10

The article is an attempt to describe three biographical motifs of H. Keller, referring to aesthetic experiences (R. Ingarden) caused by various experiences: tactile in contact with sculpture, haptic in contact with music, and literary. The starting point to consider, however, is the category of humanity in the sense of M.S. Archer. The reflexivity characteristic of humanity, combined with the aesthetic experience, makes the themes describe the non-aesthetic experiences of H. Keller. In the analysis, the author used H. Keller's correspondence, her works, biographical sources, photographs and video recordings.
\end{abstract}

KEY WORDS: humanity, H. Keller, aesthetic experience, disability culture, disability, haptic aesthetics

1 The article was created as a part of a research project titled "Towards a radical life. The social and political, as well as, social and aesthetic themes in Helen Keller's activity", conducted along with dr Sabina Pawlik at the University of Sląsk in Katowice. 


\section{Introduction}

If we adopt the category of humanity as one aiding the description of typically human phenomena and actions, differentiating us from other beings, then using it in the characteristic of cultural activity and, more precisely, artistic activity, both active - meaning the creation of the works of art, as well as, passive, related to the reception of the aforementioned, it appears almost necessary and difficult to replace with other categories. All the more, if we intend to reveal the mutual dependence between culture and art, and the social phenomena, particularly those, that shape the human being, i.e. the educational phenomena. Let us add, that the category of humanity has been present almost since the beginnings of the pedagogical thought, particularly in the theory of education and general pedagogy. Currently, the category demands reconstruction and a new take, particularly within the context of post-modern views ${ }^{2}$. The category is also useful, for the new understanding of Helen Keller's activity, who, at least on the grounds of the Polish pedagogical literature, is associated with the miracle child, or, as a precursor of new therapeutic and educational methods in working with persons with disabilities ${ }^{3}$. However, it is not the sole life of the famous woman that is interesting here, but, above all, the coherence of her views regarding culture and art with social issues.

Within this context, I perceive humanity not as a differentiating property of men, giving them a morally privileged status that humanity ${ }^{4}$, nor as a feature of contemporary social conscience lost in freedom and a relativism of values 5 , but, as described by Margaret

${ }^{2}$ M. Lipowicz, Człowieczeństwo jako (nie)zbędna kategoria refleksji pedagogicznej? O ponowoczesnym kryzysie teorii wychowania w obliczu wyzwania trans- $i$ posthumanizmu, „Studia z Teorii Wychowania” 2017, no. 2(19).

${ }^{3}$ Cf. Edukacja i rehabilitacja osób głuchoniewidomych, (eds.) Cz. Kossakowski, M. Zaorska, Wydawnictwo Uniwersytetu Warmińsko-Mazurskiego, Olsztyn 2002.

4 Por. Człowiek - wychowanie - kultura. Wybór tekstów, (ed.) F. Adamski, Wydawnictwo WAM, Kraków 1993.

${ }^{5}$ Cf. T. Nakoneczny, Ponowoczesność czyli człowieczeństwo zdegradowane, „Rocznik Teologii Katolickiej” 2014 vol. XII/1, pp. 81-103. 
S. Archer, as the "pillar of agency" 6 , as a combination of the following planes: the self, the person, the subject of action and the actor. As stated by Markieta Domecka in reference to M.S. Archer's views "Humanity as a whole, constitutes an anchorage both for the person, the subject of action, as well as, the actor. It is of fundamental meaning, as it allows to unify many varying life experiences, structural determinants, reflexive reworking and the normative expectations in one human being"7. Therefore, it creates the potential to grasp the life activity of $\mathrm{H}$. Keller as an example of actions, that may be ascribed to other individuals as well, rather than simply from the point of view of her exceptional life itself. This way, one may present her life not as a monument, ideal model to follow, but as an activity, that may be ascribed to other people and for other people.

M.S. Archer assumes, that the particular feature of humanity is reflexivity, that serves the purpose of something as a buffer zone between men and society, allowing the to remain themselves, while at the same time, be subjected to the influence of social forces, and be an active agent of the transformations that occur in the society. "[Reflexivity] performs this mediatory role by virtue of the fact that we deliberate about ourselves in relation to the social situations that we confront, certainly fallibly, certainly incompletely and necessarily under our own descriptions because that is the only way we can know anything" 8 . Therefore, the way we perceive and understand the world is tainted with our subjective, own way of thinking, feeling, through the prism of which, men attempt to make a change. M.S. Archer explains, that the mediatory function of reflexivity creates the opportunity to refer to two ontologies: the objective - specific for "social emergent properties" and subjective - characteristic

${ }^{6}$ M.S. Archer, Człowieczeństwo. Problem sprawstwa, Zakład Wydawniczy „NOMOS”, Kraków 2013.

${ }^{7}$ M. Domecka, Wprowadzenie do polskiego ttumaczenia ksiażki Margaret S. Archer "Człowieczeństwo. Problem Sprawstwa" [in:] M.S. Archer, Człowieczeństwo..., op. cit., p. XLIII.

8 M.S. Archer, Morfogeneza społeczeństwa: gdzie pasuje "Człowieczeństwo"?, [in:] Eadem, Człowieczeństwo..., op. cit., pp. LXIV-LXV. 
for "agential emergent properties. What is entailed by the above is that subjectivity is (a) real, (b) irreducible) and (c) possesses causal efficacy"9. Exactly such approach, accepting both the personal, private perspective of the human, as well as, the perspective of the subject becoming a part of social phenomena, which the subject intends to influence consciously, however, by virtue of a filter of own experiences, proves helpful in the attempt to grasp the activity of H. Keller. Writing about her, one cannot omit the issue of disability, that essentially characterised her personal identity and world experience, however, at the same time, examine her as a person involved in social actions, sensitive to the unrest and the issues of the world, that she experienced through the prism of her own, different functioning, different reception. That does not mean however, that it was of a lesser sort. I use the term "different", consciously, as it is precisely that difference, that often becomes a path, the means to show how the mankind, despite its heterogeneity caused by various factors, including disability, remains similar in fundamental matters regarding values such as, beauty, goodness, and sensitivity, in other words, that which makes us aware of our presence in the world.

One matter remains, that may be helpful in the description of the activity of aesthetic nature. It is the matter of one of the essential experiences, irremovable in contact with the works of art, culture, contact with nature, i.e. the matter of aesthetic experience. The experience is described extensively by Gorgias, Jacques Maritain and Irena Wojnar herself ${ }^{10}$, in the Polish source literature, it was promoted i.a. by Roman Ingarden. The author of the book titled "Experience, Artwork and Value" ("Przeżycie - dzieło - wartość") a work fundamental for the understanding of the category of aesthetic experience, defined it as a value of particular significance, which

${ }^{9}$ Ibidem, pp. LXV-LXVI, Cf. M.S. Archer, The Ontological Status of subjectivity: the Missing Link Between Structure and Agency, [in:] Contribution to Social Ontology, (eds.) C. Lawson, J. Spiro Latsis, N. Martins, Routledge, Abingdon 2007, pp. 17-31.

10 Cf. J. Lach-Rosocha, Pedagogia przeżycia estetycznego w wychowaniu człowieka jako osoby, Oficyna Wydawnicza „Impuls”, Kraków 2013. 
appears "against a perceived or solely imagined object (thing, process)", and it "does not allow the experiencing subject to remain "cold", but puts him in a particular state of affection"11. Due to limited space, I shall not characterise the subsequent phases of the aesthetic experience in detail, encouraging those interested to read the author himself. However, one should remind, that the aesthetic experience causes the subject to experience numerous different psychological states from the so called "initial emotion”, i.e. "initial emotion", that is the aforementioned emotion or astonishment, through the phase of a certain tuning out from the "natural course of everyday life" to the change of attitude towards an "aesthetic apprehension", characterised not by focusing on actual facts but on qualitative creations ${ }^{12}$. Therefore, an aesthetic object is constituted, which "cannot be identified with anything that is real", however, this notion of the realistic object could initiate the entire process of the aesthetic experience ${ }^{13}$. Although R. Ingarden notes, that not every aesthetic experience leads to such far-fetched consequences, i.e. to the birth of an aesthetic object, when it actually happens, the process of experiencing is not yet finished. "In the last phase [...] a particular moment is included [...] of stating, and rooting in a being a constituted aesthetic object"14. That means a certain return to reality, or even the everyday life, that contains new qualities, previously unseen.

Here, I will make a bold move of correlating the category of aesthetic experience with the M.S. Archer's understanding of reflexivity as a feature that defines humanity. The author writes that "in a nutshell, it will be maintained that the individual, as presented here in his or her concrete singularity, has powers of ongoing re1966.

11 R. Ingarden, Przeżycie - dzieło - wartość, Wydawnictwo Literackie, Kraków

12 R. Ingarden, Przeżycie estetyczne i przedmiot estetyczny, [in:] Teoria wychowania estetycznego. Wybór tekstów, (ed.) I. Wojnar, Wydawnictwo Uniwersytetu Warszawskiego, Warszawa 1994, pp. 52-53.

13 Ibidem, p. 51.

14 Ibidem, p. 55. 
flexive monitoring of both self and society, which enables this subject to make commitments in a genuine act of solidarity. These are far outside the register of 'Modernity's Man', who remains shackled to his own individualistic preference schedule. In parallel, this subject is also capable of authentic creativity, which can transform 'society's conversation' in a radical way, one which is foreign to 'Society's Being' who is condemned to making conventionally acceptable permutations upon it ${ }^{15}$, . In other words, I assume that the aesthetic experience may be one of the experiences that make men an executive, creative being, that expands beyond conventional models. Moreover, reflexivity, in combination with the aesthetic experience, may cause this "authentic creativity", which M.S. Archer refers to, to manifest in the sphere of social and not just artistic actions, however the latter may be or even are the starting point of the aesthetic experience. Thus, when we read about the radical life of H. Keller ${ }^{16}$, I mean not only her radical views, determined and uncompromising, but here primarily, I am thinking of her strive for significant changes in the social and the political life, which she described within the context or in combination with the description of aesthetic experiences.

Let us add, following Maria Popczyk, that the Ingardenian understanding of the aesthetic object is of ontological nature, his being depends on the experiencing subject, his or her acts of cognition. "The work of art is a schematic creation possessing potential place. The role of the recipient revolves around the process of instantiation, i.e. the complementation and the actualisation of underdetermined places"17. This complementary character of the aesthetic experience gains particular significance in reference to the specifics of the reception of the works of art by persons with disabilities. One should highlight, that the aesthetic experience is determined by the

${ }^{15}$ M.S. Archer, Człowieczeństwo..., op. cit., p. 297.

${ }^{16}$ Por. K.E. Nielsen, The Radical Lives of Helen Keller. (The History of Disability.) New York University Press, New York 2004.

${ }^{17}$ M. Popczyk, Przeżycie estetyczne a struktura dzieła sztuki w ujęciu Mikela Dufrenne'a i Romana Ingardena, „Folia Philosophica” 1992, no. 10, pp. 36-37. 
contemplation of the qualities of sensual things ${ }^{18}$. Due to H. Keller's legacy, we know that the dysfunctions of the sense organs turn out to be the "semaphores of a new path of the reception of the works of art and its experience" and not a barrier that keeps the persons with disabilities away from the plane of aesthetic values.

Therefore, the aim of the following article is to perform an analysis of the three biographical themes in H. Keller's life, that combine the social activity with the experience of art, referring to the aesthetic experiences produced by tactile, haptic and literary experience. I evaluate them within the theory of humanity by M. Archer and the theory of the aesthetic experience by R. Ingarden. The reflexivity, characteristic of men, as described by M. Archer, in comparison to the aesthetic experience, allows these themes to describe supraaesthetic experiences as well. The preserved rich epistolographic, photographic, video sources, biographical materials and H. Keller's own works, became the basis for the historical analyses presented below. The more valuable, as the were based on sources previously unexamined and not translated in Poland.

\section{The sculpting theme (visual-haptic)}

While speaking of the accessibility of the works of art to persons with sensory disabilities, sculpture is often given as an example of the potential contact with visual arts. This simplest, as it seems, way of experiencing art, directed by touch was not uncommon to H. Keller herself. Numerous photographs have been preserved showing how she examined the sculptures: H. Keller examining the miniature copy of the Greek Nike19, H. Keller accompanied by the sculptor Jo Davidson and the journalist Ernie Pyle, studying the surface of the E. Pyle bust made by J. Davidson with her fingers ${ }^{20}$,

18 Stownik pojęć i tekstów kultury, (ed.) E. Szczęsna, Wydawnictwa Szkolne i Pedagogiczne, Warszawa 2002, p. 60.

19 https://pl.pinterest.com/pin/450078556482987801/ [16.02.2019].

${ }^{20}$ Helen Keller studies the surfaces of sculpture, 1944 photography by Alfred Eisenstaedt https:/ /pl.pinterest.com/pin/1759287324825949/ [16.02.2019]. 
H. Keller judging her own bust made by J. Davidson21, the incredibly emotional photo of $\mathrm{H}$. Keller, touching her own face made by Yousuf Karsh 22, H. Keller touching the antique door ${ }^{23}$, etc. However, photos are not the source of the most information regarding how she experienced the contact with the works of art. Her epistolographic works from various periods of her life, are a particularly valuable source. Already as a young girl, in a letter to John Hitz from 3 February 1899, she had written: "...I had an exceedingly interesting experience last Monday. A kind friend took me over in the morning to the Boston Art Museum. She had previously obtained permission from General Loring, Supt. of the Museum, for me to touch the statues, especially those which represented my old friends in the "Iliad" and "Aeneid". Was that not lovely? While I was there, General Loring himself came in, and showed me some of the most beautiful statues, among which were the Venus of Medici, the Minerva of the Parthenon, Diana, in her hunting costume, with her hand on the quiver and a doe by her side, and the unfortunate Laocoon and his two little sons, struggling in the fearful coils of two huge serpents, and stretching their arms to the skies with heartrending cries. I also saw Apollo Belvidere. He had just slain the Python and he was standing by a great pillar of rock, extending his graceful hand in triumph over the terrible snake. Oh, he was simply beautiful! Venus entranced me. She looked as if she had just risen from the foam of the sea, and her loveliness was like a strain of heavenly music. I also saw poor Niobe with her youngest child clinging close to her while she implored the cruel goddess not to kill her last darling. I almost cried, it was all so real and tragic"24. This

${ }^{21}$ Helen Keller with her portrait by Jo Davidson - black and white photography https://pl.pinterest.com/pin/570549846517704875/ [16.02.2019].

22 Photography of H. Keller taken by Yousuf Karsh https://pl.pinterest.com/ pin/716494621948191121/ [16.02.2019] Y. Karsh (1908-2002) a Canadian of Armenian descent, one of the leading and acknowledged portrait photographers worldwide.

23 http:/ / mediastore.magnumphotos.com/CoreXDoc/MAG/Media/TR2/a/1 /a/0/PAR198304.jpg?utm_medium=Social\&utm_source=Pinterest [16.02.2019].

${ }^{24}$ H. Keller's letter to Mr. John Hitz, February 3, 1899 [in:] H. Keller, Historia mojego życia, Czytelnik, Warszawa 1967, pp. 188-189. 
moving description of the aesthetic experience of a young girl, shows not only her sensual sensitiveness, but also her knowledge regarding the culture of ancient Greece, her emotions and astonishment - emotional states that cause aesthetic experience and its development up until the constitution of the aesthetic object. This experience of the contact with the works of art aroused H. Keller's dream to go to Europe even more. These dreams were fulfilled i.a. in 1946, when Keller visited Greece, France, Italy, England, Ireland, and the Vatican ${ }^{25}$. The continent, destroyed by the war, caused reflection and outreach activity, rather than simply, aesthetic experiences. The beauty and the monumental nature of the Forum Romanum in the French Orange is mixed with the thought regarding the role of men in the shaping of the world. The manifestation of such profound aesthetic and social deliberations may be found i.a. in the correspondence with J. Davidson ${ }^{26}$.

Additionally, this part of the epistolographic work of H. Keller should be noted due to the fact that J. Davidson ${ }^{27}$ was an artist, therefore, the references to the areas of culture and art are much more justified. Moreover, the sculptor was also a person involved in political activity, which caused the a significant number of references to the current and past social events, in letters of both correspondents. As written by K.E. Nielsen "Sculptor Jo Davidson was

${ }^{25}$ K.E. Nielsen, The Radical Lives of Helen Keller..., op. cit., p. xiii.

26 Por. Letter from Helen Keller to Jo Davidson, June 19 1944, [in:] H. Keller. Selected writings, K.E. Nielsen, H.J. Kaye (eds.), New York University Press, New York 2005, pp. 227-229.

27 J. Davidson (1883-1952) was an American sculptor specialising particularly in creating busts. He is especially known as the author of busts and monuments of known individuals of the world of politics, e.g. D.D. Eisenhower, the world of art, e.g. J. Conrad, and science, e.g. A. Einstein. He was a left-wing political activist and a chairman of the Independent Citizens Committee of Artists, Scientists, and Professionals (ICCASP), an organisation that supported the policies of F. Roosevelt. He was involved in movements for racial equality, economic justice, and civil liberties. The artists created two works that presented H. Keller, her bust and a sculpture of her hands. Cf. J. Davidson, Between Sittings: an informal autobiography, The Dial Press, New York 1951. 
one of the most important of these friends and political dueling partners. Jo provided friendship and uncompromising access to the politics, intellectual debates, beauty, and joy of the rest of the world. For example, while the two were in Italy, he arranged for Helen to do a tactile "viewing" of Michelangelo and Donatello's sculptures. With him she debated theology, politics, art, and literature. Unlike many others, he dared to disagree with her outright and bluntly. When they spoke, she said, 'his whole soul flew to his tongue'. Jo characterized knowing her as 'a rich adventure'"28. From their correspondence we can learn about numerous travels, during which Keller visited art galleries, museums and antique cities. They also had mutual plans to see Israel. In one of her letters, Keller wrote "our discussions over a glass of wine and hors d'oeuvre or at a teatime or dinner about human nature, freedom, art and the nemesis of the Roman Catholic Church were to me a mine of independent thinking" 29. Reading the aforementioned gives access to the personal experiences of different degrees, however, the social and political themes are constantly present. A good example may be the letter of 24 January, 1951, where we read: "The present world situation does not look favorable for peace, and I am much worried over the censorship of news from Korea, but I hope against hope that Great Britain, India and the large peace party in France may steer our storm-tossed earth-ship into quiet waters. As you know, some say that the Korean war cannot be localized, but history gives me reason to think it can. A military man of unusual intelligence once told me that after Napoleon had been banished to St. Helena in 1811 everybody talked long and anxiously about the imminence of a general war which never broke out for a hundred years. So I hold fast to my belief that the United Nations is still 'a platform where,' as you say, 'men of different races and languages can meet and be

28 K.E. Nielsen, The Radical Lives of Helen Keller...., op. cit., p. 73.

${ }^{29}$ H. Keller to "Dear Jo and Florence," July 24, 1950, Papers of Jo Davidson, Library of Congress, in: K.E. Nielsen, The Radical Lives of Helen Keller...., op. cit., p. 101. 
heard,' and ultimately avert a third world war"30. Despite the content of the letter being different from that describing the Boston Museum experiences, a similar sensitivity emanates from it, with references being made not to mythology, but to historical events, an anxiety equally "real and tragic" as during examining the ancient Nike or the Laocoon group. One must add, that the letters are set apart by more than fifty years. It is difficult to expect a mature woman to express the enthusiasm of a nineteen-year-old. However, both these, only exemplary, fragments share the same feature of the author, that I dare to call reflexivity.

M.S. Archer wrote that "human properties and powers do not stay frozen throughout life - they do not remain just as they were at the time of their emergence" 31 . Such transformation may be observed exactly during reading $\mathrm{H}$. Keller's letters: from youth astonishment combined with comprehensive historical and cultural knowledge, to the reflections regarding the contemporary social and political situation, combined with the need of the praxis of acting for social change. Additionally, let us add that it was a need realised on high political levels. In her correspondence with J. Davidson, information regarding high political officials appear often. Both describe, e.g. their own direct meetings with the president Franklin Delano Roosevelt or the vice-president Henry Wallace ${ }^{32}$.

It is obvious, that the aforementioned results from the involvement of both authors in the local and worldwide events of the time. However, as noted by M.S. Archer, not everyone becomes an active agent. This becoming a self-aware being, capable of reflexive reference to self and to own surroundings requires time and practice, as "humanity enters society through the maternity ward doors and we immediately acquire the properties of Primary Agents through belonging to particular collectivities and sharing their privileges or

${ }^{30}$ A transciption of $\mathrm{H}$. Keller's letter to J. Davidson https://www.afb.org/ HelenKellerArchive? $a=p \& p=$ helenkellerdocumentdisplay\&d=A-HK01-03-B052-F10004.1.4\&e=en-20--1--txt$-3-7-6-5-3$ $-0-1$ [16.02.2019]

${ }^{31}$ M.S. Archer, Człowieczeństwo..., op. cit., p. 297.

32 Cf. K.E. Nielsen, The Radical Lives of Helen Keller..., op. cit., pp. 84-85. 
lack of them - as males/females; blacks/whites; foreigners/indigenous; middle class/working class" 33 , and, in the context of this article, one may also add, as able/disabled. However, the Author of Becoming Human, notes that, although we enter this world as "privileged" or "unprivileged", therefore, equipped with life opportunities differently, despite this specific determinism, or, as the author would prefer, the price that we must pay, as self-aware individuals we subject own situation to reflection and we are capable of changing it. If H. Keller hadn't demonstrated the intent to change own, former situation, maybe she would remain one of the many graduates of Perkins's school, requiring the sense of touch only to read Braille. However, the urge to change her own social "unpriveleging" led her to become a social actor, who could translate the experience of beauty for the sake of good, and extend her aesthetic sensitivity to social sensitivity.

„Infant Agents have a long way to go before they become mature Actors. Nevertheless, the kind of Agents that they start out being without any choice, due to parentage and social context, profoundly influences what type of actor they can choose to become"34. Fate threw H. Keller to find herself among a group of social individuals, to which some privileges and information had become inaccessible. However, she had the courage to pay the price in order to acquire access to these privileges. One of them was the effort of learning the world, as it is and as it allows to be learned without the use of sight and hearing. Additionally, additional aid came from the activist's social surroundings and her country of birth, which to this day is considered as a pillar of world peace, as well as, social progress.

\section{The musical theme (audio-haptic)}

Helen Keller's way of listening to music was, one may say, typical for deaf people - touch and air vibrations remained the main

33 M.S. Archer, Człowieczeństwo..., op. cit., p. 262.

34 Ibidem, p. 286. 
receptive medium. However, her receptive reactions indicated an exceptional relation to music. She felt it with her entire body. In one of the oldest records of own musical experiences, Keller wrote: "I stood in the middle of the church, where the vibrations from the great organ were strongest, and I felt the mighty waves of sound beat against me, as the great billows beat against a little ship at sea." 35 . Thus, the aesthetic that she had experienced at the time was of a nature much greater than tactile, it was corporeal, haptic, but in a particular meaning: received by the haptic system, i.e. the system comprising of skin, muscles, joints, tendons, and receptors scattered across all of them. James J. Gibson describes the haptic system as that, which allows the human being or the animal to feel the surrounding environment by the virtue of own body, or its remote members. The system is comprised not only of the pressure on the skin, or the kinaesthetic sensations, but also all information regarding the environment or own body: the relations of a given object to the body, and in reverse, the body to the object ${ }^{36}$. This indicates, that the haptic system is not only a passive receptive system, but a complex active construction allowing to stay "in touch" 37 , i.e. in contact with the surroundings. The preserved video records showing H. Keller listening to music, are exactly a symptomatic example of such haptic listening to music. In one of the videos, Keller is listening to Jascha Heifetz ${ }^{38}$, and she said, that the experienced vibrations awoke feelings of sadness, happiness, as well as, loneliness in her. She described the singing of the mezzo-soprano opera singer Gladys Swarthout ${ }^{39}$ as as beautiful as everyday prayer. One must add, that Keller, while standing by the piano, would listen to the opera singer while touching her face, and so she was able to deci-

${ }^{35}$ H. Keller's letter to Mrs. Laurence Hutton, 2 January 1900 [in:] H. Keller, Historia mojego życia..., op. cit., p. 198.

36 J.J. Gibson, The Senses Considered as Perceptual System, Houghton Mifflin, Boston 1966, pp. 97-98.

37 Ibidem, p. 98.

38 https:/ / www.youtube.com/watch?v=oZxHxSrLqqU [17.03.2019]

${ }^{39}$ Helen Keller "Listens" to Gladys Swarthout Sing: https://www.youtube. com/watch?v=WdOKL7KZeos [17.03.2019] 
pher at least a part of the lyrics sung, which actually were a prayer. Among the singers, that H. Keller listened to, were Enrico Caruso, Lauritz Melchior, and, beyond the world of the opera, Benny Goodman. However, that which remains particularly interesting, is the external reception of the musical aesthetic experience, expressed in motion, facial expression and the body movement of the listener. A careful observation of even brief fragments of the records of the reception of the musical pieces indicates, how the expression changed accordingly to the changes in the musical qualities of the piece. H. Keller's motion creates a harmonic unity in accordance with the changes in pace, the flow of the pieces' dynamics, pitch scale, and the accompaniment. Additionally, the records of the emotional reactions of $\mathrm{H}$. Keller play the role of indisputable evidence for her musical sensitivity, and for her ability to establish contact with music for deaf persons in general. Moreover, the aforementioned constitute an essential argument against those who doubt the authenticity of the experience, which $\mathrm{H}$. Keller described in her letter to the New York Philharmonic, written in March 1924, after she had listened their performance of the Beethoven's Ninth. Then, she wrote: "[...] I could feel, not only the vibration, but also the impassioned rhythm, the throb and the urge of the music! The intertwined and intermingling vibrations from different instruments enchanted me. I could actually distinguish the cornets, the roil of the drums, deep-toned violas and violins singing in exquisite unison. How the lovely speech of the violins flowed and plowed over the deepest tones of the other instruments! When the human voices leaped up thrilling from the surge of harmony, I recognized them instantly as voices more ecstatic, upcurving swift and flame-like, until my heart almost stood still. The women's voices seemed an embodiment of all the angelic voices rushing in a harmonious flood of beautiful and inspiring sound. The great chorus throbbed against my fingers with poignant pause and flow. Then all the instruments and voices together burst forth - an ocean of heavenly vibration - and died away like winds when the atom is spent, ending in a delicate shower of sweet notes. [...] the tones and harmonies conveyed to me moods of great beauty and majesty. I also sense, or thought I did, the tender 
sounds of nature that sing into my hand-swaying reeds and winds and the murmur of streams. I have never been so enraptured before by a multitude of tone-vibrations." 40 . The beautiful description of the aesthetic experience, that Beethoven's music had produced, is not simply something that awakes emotions. It also shows the variety of sensual experiences of received vibrations and meanings given to them, notabene consistent with the piece's composition, that is difficult to imagine for a hearing person. It is a description of a haptic pleasure, caused by the world of sounds, received as vibrations. Listening to the Ninth Symphony by the speaker's membrane, had come as a surprise to the listener, a surprise that the deaf persons could actually participate in experiencing music in other ways than the live performances.

This way of coming into contact with art (music), new for the time, evokes a supra-aesthetic aspect to the theme, related to technology and education. On the one hand, it suggests that the technological achievements may open new areas, previously inaccessible, for persons with disabilities, however, on the other hand, it shows the human helplessness in regard to varying educational strategies, particularly the traditional ones, aiming at likening of the functioning of persons with disabilities to the way it occurs in a society dominated by able persons. Let us begin with supplementing the musical theme with some biographical information about $\mathrm{H}$. Keller. It seems, that the interest in music is included in her general nature, being the curiosity regarding the world, therefore, music would interest her in varying aspects. Both receptive and creative. In a letter describing the experiences from visiting the World's Fair, Keller mentioned that "the queer-looking Japanese musical instruments, and their beautiful works of art were interesting" 41 . However, it was not just the reception of music that would fascinate H. Keller.

${ }^{40}$ Helen Keller Letter on Beethoven's Ninth Symphony Goes Viral, https:// www.afb.org/blog/entry/helen-keller-letter-beethovens-ninth-symphony-goes-viral [1.03. 2019].

${ }^{41}$ Helen Keller's letter to Miss Caroline Derby, August 17, 1893 [in:] H. Keller, Historia mojego życia, op. cit., p. 168. 
We know, that she took piano lessons at the Perkins' School. In one of her letters to Caroline Derby, she wrote: "I enjoy my singing lessons with Dr. Humason more than I can say. I expect to take piano lessons sometime..."42. The experimental instrument playing lessons turned out to be a failure, closing the path to musical performance, at least at an amateur level. However, one should add that given $\mathrm{H}$. Keller's enormous motivation to come in an active contact with music, now such a chance would not go forfeit. Within the circles of contemporary music therapists, the application of various techniques of coming into contact with music, also active, based on using musical instruments while working with deaf persons, even with a severe hearing deficiency, is practised universally. Moreover, the surdo music therapy, apart from training hearing, also contributes to the development of such aspects as speech and language ${ }^{43}$.

Obviously, the development of therapeutic methods based on art, including music therapy, and their broad applications in working with persons with disabilities as well as able persons is dictated, i.a. by a paradigmatic change, accepting the heterogeneous nature of the human population, and even by adopting the cultural paradigm ${ }^{44}$. Such approach was not universal in the $19^{\text {th }}$ century, and even the second half of the $20^{\text {th }}$ century, resulting, i.a. in promoting the oral method as the most effective and the best method for educating deaf persons ${ }^{45}$. Despite the fact, that $\mathrm{H}$. Keller loved the

${ }^{42}$ Helen Keller's letter to Miss Caroline Derby, October 23, 1894 [in:] H. Keller, Historia mojego życia, op. cit., p. 171.

${ }^{43}$ K.E. Gfeller, Music therapy in the treatment of sensory disorders [in:] An Introduction to Music Therapy: Theory and Practice, (eds.) W.B. Davis, K.E. Gfeller, M.H. Thaut, McGraw-Hill College, Dubuque 1999, pp. 189-193. Cf. A. Darrow, H. Grohe, Music therapy for learners who are deaf or hard-of-hearing [in:] Models of Music Therapy interventions in school settings, (ed.) B. Wilson, Silver Spring, American Music Therapy Association 2002. pp. 291-304; A. Flis, Muzykoterapia jako wsparcie rozwoju dzieci niestyszacych, „Polskie Pismo Muzykoterapeutyczne” 2015, no. 2, pp. 23-49.

${ }^{44} \mathrm{Cf}$. A. Krauze, Wspótczesne paradygmaty pedagogiki specjalnej, Oficyna Wydawnicza „Impuls”, Kraków 2010; I. Chrzanowska, Pedagogika specjalna. Od tradycji do wspótczesności, Oficyna Wydawnicza „Impuls”, Kraków 2015, pp. 387-421.

${ }^{45}$ L. Crow, Helen Keller: Rethinking the Problematic Icon, "Disability \& Society", 2000, Vol. 16, No. 6, p. 7, 15. 
"singing lessons" and considered the possibility to study at the Wright-Humason School for the Deaf, the lessons were primarily aimed at increasing the strength of her voice, teaching her to speak, and developing the ability of lip-reading ${ }^{46}$.

However, on the other hand, one should consider the essential question whether the emphasis on speech use by deaf persons contributed to the construction of such inventions as auditory apparatus and cochlear implants. We must remember, that it was exactly the attempts to find a way of contacting with deaf persons, that inspired Abraham Bell to create a prototype of the invention, which would later become the modern telephone. Following this trail, one cannot forget about the use of the aforementioned radio and disc records in the education of blind persons. She argued for that, but not exactly due to the fascination with technology. She saw the record industry as the path to promote literature, particularly, among those who had difficulty with mastering the Braille alphabet, e.g. due to the insufficient tactile sensitivity of the fingers, caused, e.g. by age or profession. The records could introduce children who wouldn't be able to read yet, to the world of literature. Finally, a no less significant argument: a record weighs less and is smaller than a book written in Braille.

\section{The literary theme}

Regardless of how one looks at H. Keller's education, it must be said that she received thorough schooling in humanities. The reading of classical literature was the basis of her learning, shaping reflexivity, and her natural way of looking at social phenomena. However, one must add, that the results she achieved, were supported with hard work. Both in the Story of My Life, as well as, in the letters from the schooling period, we shall easily find numerous information in her effort of acquiring knowledge, e.g. "I am afraid

${ }^{46}$ K.E. Nielsen, The Radical Lives of Helen Keller...., op. cit., p. 7. 
this letter savors too much of books-- but really they make up my whole life these days, and I scarcely see or hear of anything else! I do believe I sleep on books every night! You know a student's life is of necessity somewhat circumscribed and narrow and crowds out almost everything that is not in books..." 47 . The access to literature was no doubt made possible to Keller, due to her extraordinary language skills. She would read Braille in both English, French, German, as well as, classical languages - Latin and Greek. About the last of the mentioned languages, she had written that: "If it is true that the violin is the most perfect of musical instruments, then Greek is the violin of human thought ${ }^{\prime \prime} 48$. Moreover, the teachers and subsequent friends of H. Keller, Anne Sulivan and Polly Thompson, were much aid to her, as they would read books and papers, and Keller could understand the contents by lip-reading and fingerspelling. The list of works is quite substantial, however, let us take note of those most mentioned: Homer and his Iliad, as well as, the Odyssey, the Aeneid and the Eclogues by Virgil, works by Cicero and Homer, Jean de La Fontaine's Fables, drama works by Aeschylus, Pierre Corneille, Molier and William Shakespeare, the works of Joseph Rudyard Kipling, e.g. the Kitchener's School, Francis Bacon's Essays, and A History of the English People by John Richard Green ${ }^{49}$. This initial list of lectures already suggests, that H. Keller's schooling and later self-learning curriculum was of a classical nature. One must add, that some of the selected works were H. Keller's own choice. However, while remembering that she possessed a thorough knowledge regarding history and the culture of the countries of origin of the selected works, her interpretations included social thoughts, rather than personal. While, in one of the letters, an eighteen-year-old student allowed herself to make a rather romantic

${ }^{47}$ H. Keller's letter to Mr. John Hitz, February 3, 1900 [in:] H. Keller, Historia mojego życia, op. cit., p. 199.

${ }^{48}$ H. Keller's letter to Mrs. Laurence Hutton, February 20, 1898L [in:] H. Keller, Historia mojego życia, op. cit., p. 182.

${ }^{49}$ H. Keller, Historia mojego życia, op. cit.; Cf. H. Keller. Selected writings, (eds.) K.E. Nielsen, H.J. Kaye, op. cit. 
comparison of the Aeneid and the Iliad to a beautiful maiden, living in a palace, surrounded by a magnificent court (Aeneid) and to a brilliant young man has had the earth for his playground (Iliad) ${ }^{50}$, just a few months later she would write: "The Iliad tells of almost nothing but war, and one sometimes wearies of the clash of spears and the din of battle, but the Odyssey tells of a nobler courage--the courage of a soul sore tried, but steadfast to the end. I often wonder, as I read these splendid poems why, at the same time that Homer's songs of war fired the Greeks with valor, his songs of manly virtue did not have a stronger influence upon the spiritual life of the people. Perhaps the reason is, that thoughts truly great are like seeds cast into the human mind, and either lie there unnoticed, or are tossed about and played with, like toys, until, grown wise through suffering and experience, a race discovers and cultivates them. Then the world has advanced one step in its heavenward march"51. The social attitude in experiencing the part of the works, reading them through the prism of the history of a group, a nation, rather than, through the prism of individuals, even as heroic as Achilles, Agamemnon, Odysseus is characteristic for H. Keller's way of treating literary works, and not only in her youth. Jo Davidson would mention, how he secured the Braille translations of Anatole France's Penguin Island and the Revolt of Angels, as well as, Voltaire's Candide $e^{52}$. In reply, and one must note that she was seventy-years old, Keller wrote: "It was more than I could have hoped, having you there [in France - ed.] while I read them and hearing your comments upon their significance and their influence upon France"53. However, if the way of Keller's aesthetic experience of the literary works was not complemented by actual social activity, it could pos-

${ }^{50}$ H. Keller's letter to Mrs. Laurence Hutton, October 23, 1898 [in:] H. Keller, Historia mojego życia, op. cit., p. 185.

${ }^{51}$ H. Keller's letter to Dr. David H. Greer, May 8, 1899 [in:] H. Keller, Historia mojego życia, op. cit., p. 191.

52 K.E. Nielsen, The Radical Lives of Helen Keller..., op. cit., p. 101.

53 HK to "Dear Jo and Florence," July 24, 1950, Papers of Jo Davidson, Library of Congress, after: K.E. Nielsen, The Radical Lives of Helen Keller..., op. cit., p. 101. 
sibly be considered as childish or simply utopian. Meanwhile, the activist who analysed literature within the aspect of its influence on the society, had become one of the most significant persons who would involve themselves in the fight for the rights of women, persons with disabilities, or in the activity for world peace. It was a result, as she herself states, from one of her characteristic features optimism $^{54}$. In a small book, an essay of the same title, while referring to Shakespeare's drama works, she wrote: "Shakespeare is the prince of optimists. His tragedies are a revelation of moral order. In Lear and Hamlet there is a looking forward to something better, some one is left at the end of the play to right wrong, restore society and build the state anew. The later plays, The Tempest and Cymbeline show a beautiful, placid optimism which delights in reconciliations and reunions and which plans for the triumph of external as well as internal good"55. Obviously, it would be too far a fetched, and a simply wrong simplification to state, that $\mathrm{H}$. Keller looked at the world through the prism of literature: mythology, fiction, and drama. Most definitely not. The radicalism of some of her beliefs, e.g. regarding eugenics, public health care, and poverty, suggests that she had both her feet well on the ground 56 . She was also aware of her own difficulties related to breaking the stereotypes regarding disabilities on the one hand, and the stereotypes of a wonder child. However, it was the literature, particularly classical, in combination with her historical knowledge, that shaped her way of understanding social phenomena. Possibly, it may have contained some part of the youthful belief in that one can change the world, and that it may be given an aesthetic form.

In one of her letters, Keller wrote: "Some of my friends tell me that I am very foolish to give so much time to Greek and Latin; but I am sure they would not think so, if they realized what a wonderful world of experience and thought Homer and Virgil have opened up

${ }^{54}$ Cf. H. Keller, Optimism: an essay, Bottom of the Hill, Memphis 2011 (original, 1903 edition).

55 Ibidem, p. 35.

56 Cf. K.E. Nielsen, The Radical Lives of Helen Keller...., op. cit., pp. 36-37. 
to me" 57 . One must add, that it was not a type of fable wonders, filled with the world of "knights [...], fairies, dragons and all sorts of strange creatures" 58 , which $\mathrm{H}$. Keller saw as grotesque, however, beautiful. The wonder of the world of Homer and Virgil is the basis of the Euro-American, dominant culture, in which H. Keller, as we all, lived.

\section{Summary}

The attempt to describe the selected social and aesthetic themes in the activity of H. Keller, as presented above, in no way exhausts the entirety of the subject. However, I intend to propose, hopefully so, a different view on her biography. A look, in which I have consciously attempted to escape the barriers denoted by chronology, historical events, or the political activity of the article's heroine. My attempt was to present her as a person of great aesthetic sensitivity, experiencing the contact with art in an emotional, reflexive way. However, I did not want for this sensitivity to obscure the activity which H. Keller established as her life purpose. Already in 1901 she would write that "I am deeply interested in politics. I like to have the papers read to me, and I try to understand the great questions of the day; but I am afraid my knowledge is very unstable; for change my opinions with every new book I read. I used to think that when I studied Civil Government and Economics, all my difficulties and perplexities would blossom into beautiful certainties; but alas, I find that there are more tares than wheat in these fertile fields of knowledge..." 59 . However, H. Keller faced the challenge related to social activism and the involvement in politics, and so she went

57 Helen Keller's letter to David H. Greer, May 81899 [in:] H. Keller, Historia mojego życia, op. cit., p. 191.

58 Helen Keller's letter to John Hitz, February 3, 1900 [in:] H. Keller, Historia mojego życia, op. cit., p. 199.

${ }^{59}$ Helen Keller's letter to the honourable George Frisbie Hoar, November 25, 1901 [in:] H. Keller, Historia mojego życia, op. cit., p. 199. 
down in history, but in this aspect, she is better known to the United States and the Great Britain societies, rather than to the Poles.

The gathered epistolographic sources, partially translated to Polish, partially original, visual sources (photographies) and audiovisual (video records), as well as, English-language source literature that presents H. Keller's life in the period following the Story of My Life, as well as, publications of $\mathrm{H}$. Keller herself, provoked me to focus on the themes, where the author is speaking of herself, and presents the world from a personal perspective, determined by the alternative experience thereof. I use the word "alternative" as, due to the descriptions of H. Keller's aesthetic experiences, the contemporary directions of aesthetic pursuits are no longer a surprise. Touching the visual art, haptic music listening, listening to literature rather than reading it, are becoming more and more universal, not only in the spheres reserved for people with disabilities. However, what does an experience of beauty have in common with social activism? H. Keller provided an answer herself: "A gentleman asked me what BEAUTY meant to my mind. I must confess I was puzzled at first. But after a minute I answered that beauty was a form of goodness--and he went away" 60 .

Placing the analysis presented above, within the contemporary theory of M. Archer's humanity, shows how beautifully these two aspects of H. Keller's life, i.e. the aesthetic and the social, are intertwined. It allows to avoid an often occurring, but stereotypical premise, that people sensitive to beauty and works of art, are equally sensitive to social phenomena. The examples of Adolf Hitler and Hermann Göringa belie that belief. Therefore, not stopping on the category of an aesthetic experience, but combining it with the theory of humanity, particularly with the characteristic of reflexivity, allowed to reveal the more intricate relations. The childhood experience, the personal traits, a combination of sensory and intellectual sensitivities, with an extraordinary knowledge regarding history,

${ }^{60} \mathrm{H}$ Keller's letter to Mrs. Kate Adams Keller, April 13, 1893 [in:] H. Keller, Historia mojego życia, op. cit., p. 165. 
and the awareness of the surrounding social changes, allow to see the life work of H. Keller also as Archer's "pillar of agency", i.e. this unity of the self, the person, and the subject. It is extremely important, particularly in the current time, with one of the dominant themes are questions regarding the future of mankind, as well as, its transhumanist or post-humanist nature. The analysis of Helen Keller's biographical themes suggests, that the problems regarding mankind cannot be limited to the analysis of the human body, even if we assume, after R. Ingarden, that cognition begins in the processes of receiving impressions and perception processing. The philosopher argues how such process is developed, and the records of H. Keller's experiences, preserved to this day, greatly specify the course of these processes.

If the task of the human reflexivity is to refer refer both to subjective and to objective beings, as assumed by M. Archer's theory, then the themes presented above reveal the coherence of these two ontologies. However, usually in the works regarding the artistic and the cultural activities of persons with disabilities, there is a lack of such coherence. Numerous attempts of describing the participation of persons with disabilities in culture are made, however, from the perspective of able persons. It comes from the fact that the subjective perspective of such activities of the persons with disabilities is still not publicised enough. We still know too little about how they experience it both on the sensory level, of the aesthetic experience, and of the following consequences, related, e.g. with creating a new reception of the works of art.

H. Keller's legacy has practical implications in numerous projects combining artistic and social activities. A number of art therapy project may serve as examples, such as Between water and words: Reflective self-awareness and symbol formation in art therapy, Destiny Lofts-In Memory of Helen Keller regarding space design, motivational speaker inspiration (Sonny Melendrez), as well as, the development of haptic aesthetics, or the research regarding the disability culture. However, the material collected by the author of the article, abundant in numerous examples, deserves to be presented in a separate 
publication, one that is prepared in the project titled Towards a radical life. The social and political, as well as, social and aesthetic themes in Helen Keller's activity (W strone radykalnego życia. Społeczno-polityczne $i$ społeczno-estetyczne watki działalności Helen Keller), for which this article serves as the theoretical part.

\section{Bibliography}

Archer M.S., Człowieczeństwo. Problem sprawstwa, Zakład Wydawniczy „NOMOS”, Kraków 2013.

Archer M.S., Morfogeneza społeczeństwa: gdzie pasuje "Człowieczeństwo"?, [in:] M.S. Archer, Człowieczeństwo Problem sprawstwa, Zakład Wydawniczy „NOMOS”, Kraków 2013.

Archer M.S., The Ontological Status of subjectivity: the Missing Link Between Structure and Agency, [in:] Contribution to Social Ontology, (eds.) C. Lawson, J. Spiro Latsis, N. Martins, Routledge, Abingdon 2007.

Chrzanowska I, Pedagogika specjalna. Od tradycji do wspótczesności, Oficyna Wydawnicza „Impuls”, Kraków 2015.

Crow L., Helen Keller: Rethinking the Problematic Icon, "Disability \& Society", 2000, Vol. 16, No. 6.

Człowiek - wychowanie - kultura. Wybór tekstów, (ed.) F. Adamski, Wydawnictwo WAM, Kraków 1993.

Darrow A., Grohe H., Music therapy for learners who are deaf or hard-of-hearing, [in:] Models of Music Therapy interventions in school settings, (ed.) B. Wilson, Silver Spring, American Music Therapy Association 2002.

Davidson J., Between Sittings: an informal autobiography, The Dial Press, New York 1951.

Domecka M., Wprowadzenie do polskiego ttumaczenia książki Margaret S. Archer "Cztowieczeństwo. Problem Sprawstwa", [in:] M.S. Archer, Człowieczeństwo Problem sprawstwa, Zakład wydawniczy „NOMOS”, Kraków 2013.

Edukacja i rehabilitacja osób głuchoniewidomych, (eds.) Cz. Kossakowski, M. Zaorska, Wydawnictwo Uniwersytetu Warmińsko-Mazurskiego, Olsztyn 2002.

Flis A., Muzykoterapia jako wsparcie rozwoju dzieci niestyszacych, „Polskie Pismo Muzykoterapeutyczne" 2015, no. 2, pp. 23-49.

Gfeller K.E., Music therapy in the treatment of sensory disorders [in:] An Introduction to Music Therapy: Theory and Practice, red. W.B. Davis, K.E. Gfeller, M.H. Thaut, McGraw-Hill College, Dubuque 1999.

Gibson J.J., The Senses Considered as Perceptual System, Houghton Mifflin, Boston 1966. 
Ingarden R., Przeżycie - dzieło - wartość, Wydawnictwo Literackie, Kraków 1966.

Ingarden R., Przeżycie estetyczne i przedmiot estetyczny [in:] Teoria wychowania estetycznego. Wybór tekstów, (ed.) I. Wojnar, Wydawnictwo Uniwersytetu Warszawskiego, Warszawa 1994.

Keller H., Optimism: an essey, Bottom of the Hill, Memphis 2011.

Krauze A., Wspótczesne paradygmaty pedagogiki specjalnej, Oficyna Wydawnicza „Impuls”, Kraków 2010.

Lach-Rosocha, J., Pedagogia przeżycia estetycznego w wychowaniu człowieka jako osoby, Oficyna Wydawnicza „Impuls”, Kraków 2013.

Lipowicz, M. Człowieczeństwo jako (nie)zbędna kategoria refleksji pedagogicznej? O ponowoczesnym kryzysie teorii wychowania w obliczu wyzwania trans- $i$ posthumanizmu, „Studia z Teorii Wychowania” 2017, no. 2 (19), pp. 35-57.

Nakoneczny T., Ponowoczesność czyli człowieczeństwo zdegradowane, „Rocznik Teologii Katolickiej” 2014 vol. XII/1, pp. 81-103.

Nielsen K.E., The Radical Lives of Helen Keller. (The History of Disability.) New York University Press, New York 2004.

Popczyk, M., Przeżycie estetyczne a struktura dzieła sztuki w ujęciu Mikela Dufrenne'a i Romana Ingardena, „Folia Philosophica” 1992, no. 10, pp. 36-37.

Stownik pojęć i tekstów kultury, (ed.) E. Szczęsna, Wydawnictwa Szkolne i Pedagogiczne, Warszawa 2002.

\section{Helen Keller's letters}

H. Keller to “Dear Jo and Florence," July 24,1950, Papers of Jo Davidson, Library of Congress

Helen Keller Letter on Beethoven's Ninth Symphony Goes Viral, https://www. afb.org/blog/entry/helen-keller-letter-beethovens-ninth-symphony-goes-viral [1.03. 2019]

Letter from Helen Keller to Jo Davidson, June 19 1944, [in:] H. Keller. Selected writings, red. K.E. Nielsen, H.J. Kaye, New York University Press, New York 2005

H. Keller's letter to Dr. David H. Greer, May 8, 1899 [in:] H. Keller, Historia mojego życia, Czytelnik, Warszawa 1967.

H. Keller's letter to Mr. John Hitz, February 3, 1899 [in:] H. Keller, Historia mojego życia, Czytelnik, Warszawa 1967.

H. Keller's letter to Mrs. Kate Adams Keller, April 13 1893,[in:] H. Keller, Historia mojego życia, Czytelnik, Warszawa 1967.

H. Keller's letter to Mrs. Laurence Hutton, October 231898 [in:] H. Keller, Historia mojego życia, Czytelnik, Warszawa 1967.

H. Keller's letter to Mrs. Laurence Hutton, January 2, 1900 r. [in:] H. Keller, Historia mojego życia, Czytelnik, Warszawa 1967.

H. Keller's letter to Ms. Caroline Derby, July 17, 1893 [in:] H. Keller, Historia mojego życia, Czytelnik, Warszawa 1967. 
H. Keller to the honourable George Frisbie Hoar do wielmożnego George Frisbie Hoar, November 25, 1901 [in:] H. Keller, Historia mojego życia, Czytelnik, Warszawa 1967.

A transcription of H. Keller's letter to J. Davidson

https:/ / www.afb.org/HelenKellerArchive? $a=p \& p=h e l e n k e l l e r d o c u m e n t d i s p l a y \& d$ =A-HK01-03-B052-F10-004.1.4\&e=-------en-20--1--txt--------3-7-6-5-3-------------0-1 [16.02.2019]

Fotografie

Photography of $\mathrm{H}$. Keller taken by Yousuf Karshhttps://pl.pinterest.com/pin/ 716494621948191121/ [16.02.2019]

Helen Keller studies the surfaces of sculpture, 1944 photography by Alfred Eisenstaedthttps://pl.pinterest.com/pin/1759287324825949/ [16.02.2019]

Helen Keller with her portrait by Jo Davidson - black and white photography https:/ / pl.pinterest.com/pin/570549846517704875/ [16.02.2019]

http:/ / mediastore.magnumphotos.com/CoreXDoc/MAG/Media/TR2/a/1/a/0/

PAR198304.jpg?utm_medium=Social\&utm_source=Pinterest [16.02.2019]

https:/ /pl.pinterest.com/pin/450078556482987801/ [16.02.2019]

Video

https:/ / www.youtube.com/watch?v=oZxHxSrLqqU [17.03.2019]

Helen Keller „Listens” to Gladys Swarthout Sing

https:/ / www.youtube.com/watch?v=WdOKL7KZeos [17.03.2019] 